\title{
PENGARUH PENEMPATAN KARYAWAN DAN KOMPENSASI TERHADAP KINERJA KARYAWAN PT SOCFIN INDONESIA MEDAN
}

\author{
Hermanto Manalu \\ Alumni Jurusan Manajemen Fakultas Ekonomi Universitas Negeri Medan \\ Riza Indriani \\ Dosen Jurusan Manajemen Fakultas Ekonomi Universitas Negeri Medan
}

\begin{abstract}
Abstrak
Latar belakang penelitian ini adalah, apakah penempatan karyawan dan kompensasi berpengaruh terhadap kinerja karyawan PT Socfin Indonesia Medan. Berdasarkan latar belakang tersebut maka tujuan penelitian ini adalah untuk mengetahui dan menjelaskan pengaruh penempatan karyawan dan kompensasi terhadap kinerja karyawan PT Socfin Indonesia Medan. Populasi dalam penelitian ini adalah sebanyak 168 karyawan, sedangkan sampel sebanyak 63 karyawan. Teknik penentuan sampel dalam penelitian ini menggunakan rumus slovin. Teknik pengumpulan data menggunakan kuisioner. Teknik analisis data yang digunakan adalah regresi linier berganda. Dari hasil uji validitas diperoleh $r$ hitung $>r$ tabel untuk masing-masing item pernyataan dan uji reliabilitas angket diperoleh alpha cronbach masing-masing variabel yaitu 0,729 untuk variabel $X_{1}, 0,890$ untuk variabel $X_{2}$ dan 0,818 untuk variabel Y. Nilai ini lebih besar bila dibandingkan dengan nilai $r_{\text {tabel }}$ pada taraf signifikan 95\% dan df-2 $=30-2=$ 28 yaitu 0,361. Analisis data masing-masing variabel diperoleh persamaan regresi berganda $Y=17,582+0,730 X_{1}+0,630 X_{2}+e$, yang artinya kinerja karyawan akan konstan sebesar 17,582 jika tidak dipengaruhi oleh variabel penempatan karyawan dan kompensasi. Uji parsial pada $X_{1}$ sebesar 5,240 dan $X_{2}$ sebesar 4,613, lebih besar dibanding dengan t-tabel dengan $d f=n-k=63-3=60$ yaitu sebesar 2,000 pada taraf signifikan 5\%. Uji simultan dengan menggunakan tabel ANOVA dengan angka sig penelitian yang diperoleh dari hasil perhitungan sebesar 0,000 $<0,05$ yang artinya hipotesis diterima yaitu penempatan karyawan dan kompensasi secara bersama-sama berpengaruh signifikan terhadap kinerja karyawan pada PT Socfin Indonesia Medan.
\end{abstract}

Kata Kunci : Penempatan Karyawan, Kompensasi, Kinerja Karyawan

\section{PENDAHULUAN}

Tujuan organisasi akan lebih mudah dicapai apabila kinerja dari karyawan baik. Kinerja yang baik akan tercipta apabila karyawan memiliki kompetensi yang baik juga. Tetapi kompetensi saja tidak cukup untuk meningkatkan kinerja karyawan, dibutuhkan juga ketepatan dalam menempatkan karyawan sesuai dengan kompetensi yang dimilikinya. Menurut Hasibuan (2005:202), penempatan karyawan harus didasarkan pada job description dan job specification yang telah ditentukan serta berpedoman kepada prinsip "The right man on the right place and the right man behind the job". Hal ini akan membawa suatu instansi kepada hasil kerja yang optimal karena terdapat adanya korelasi positif antara penempatan karyawan dengan peningkatan kinerja karyawan. Penempatan karyawan secara tepat akan menghasilkan kinerja karyawan yang baik, berdaya guna dan berhasil. 


\begin{abstract}
Karyawan memberikan prestasi kinerja yang baik untuk kemajuan organisasi, sedangkan organisasi memberikan kompensasi yang sesuai atas kinerja yang telah diberikan karyawan terhadap organisasi. Pemberian kompensasi sangat penting bagi karyawan, karena besar kecilnya kompensasi merupakan ukuran terhadap kinerja karyawan.
\end{abstract}

Pemberian kompensasi dapat meningkatkan kinerja dan motivasi karyawan. Oleh karena itu, perhatian organisasi atau perusahaan terhadap pengaturan secara rasional dan adil sangat diperlukan. Bila karyawan memandang pemberian kompensasi tidak memadai, prestasi kerja/kinerja cenderung akan menurun. Seseorang yang bekerja akan merasa lebih dihargai oleh masyarakat di sekitarnya, dibandingkan yang tidak bekerja. Untuk menjamin tercapainya keselarasan tujuan, pimpinan organisasi bisa memberikan perhatian dengan memberikan kompensasi, karena kompensasi merupakan bagian dari hubungan timbal balik antara organisasi dengan sumber daya manusia.

PT. Socfindo Medan merupakan perusahaan swasta yang bergerak dibidang perkebunan kelapa sawit dan karet. Didirikan pada tahun 1930 dengan nama Socfindo Medan SA (Societe Financiere Des Caoutchoucs Medan Societe Anonyme). Berdasarkan hasil wawancara dengan beberapa karyawan, penempatan karyawan di PT. Socfin Indonesia sudah dilaksanakan sesuai prosedur. Karyawan ditempatkan di posisi yang sesuai dengan keahlian masingmasing karyawan. Selain keahlian, hal yang dipertimbangkan dalam penempatan karyawan di PT. Socfin Indonesia adalah usia dan latar belakang pendidikan. Hal ini ditentukan pada saat perusahaan mengadakan perekrutan dan seleksi karyawan untuk suatu jabatan tertentu. Pada saat perekrutan perusahaan menentukan tingkat pendidikan dan pengalaman yang harus dimiliki calon karyawan. Gaji/upah yang diterima karyawan juga sudah dapat memenuhi kebutuhan karyawan.

Penempatan karyawan adalah pemberian sebuah posisi/jabatan dan tanggung jawab kepada karyawan, dimana posisi/jabatan tersebut sesuai dengan keahlian dan kemampuan yang dimiliki oleh karyawan.

Adapun Indikator Penempatan Karyawan Menurut Wahyudi (dalam Suwatno 2008:129) adalah:

1. Pendidikan

2. Pengetahuan kerja

3. Keahlian / keterampilan kerja

4. Pengalaman kerja

Kompensasi adalah segala bentuk pembayaran yang diberikan oleh perusahaan kepada karyawan sebagai umpan balik atas kinerja yang diberikan oleh karyawan terhadap perusahaan

Adapun indikator kompensasi menurut Simamora (2006:445) adalah:

1. Upah dan gaji

2. Insentif

3. Tunjangan

4. Fasilitas

Kinerja karyawan adalah hasil kerja seorang karyawan dalam suatu organisasi yang dilihat dari segi kualitas dan kuantitas, dan sesuai 
dengan tanggung jawab yang diberikan dalam rangka mencapai tujuan organisasi.

Adapun indikator kinerja karyawan Menurut Soedjono (2005) adalah:

1. Kualitas

2. Kuantitas

3. Efektivitas

4. Ketepatan waktu

5. Kemandirian

6. Komitmen kerja

7. Tangggungjawab

\section{METODE PENELITIAN \\ Teknik Analisis Data \\ Uji Instrumen}

Untuk melihat hubungan pengaruh variabel bebas terhadap variabel terikat, penulis menggunakan analisis: Uji Validitas, Uji Reliabilitas.

\section{Uji Asumsi Klasik}

Pada uji regresi linier berganda perlu diadakan uji asumsi klasik. Uji ini bertujuan untuk memenuhi asumsi normalitas data dan apakah terbebas dari multikolinieritas, autokorelasi dan heteroskedastisitas. Berikut penjelasan untuk ketiga asumsi tersebut.

a. Uji Normalitas

b. Uji Multikolinieritas

c. Uji Heteroskedastisitas

Analisis Regresi Linier Berganda

Menurut Kuncoro (2003:215) regresi linier berganda bertujuan untuk melihat secara langsung pengaruh beberapa variabel bebas terhadap variabel terikat.

Persamaan regresi linier berganda dapat dituliskan sebagai berikut:

$$
\boldsymbol{Y}=a+b_{1} x_{1}+b_{2} x_{2}+e
$$

\section{Uji Hipotesis}

Uji t

Untuk menguji secara parsial apakah variabel bebas $\left(\mathrm{X}_{1}, \mathrm{X}_{2}\right)$ memiliki pengaruh yang signifikan terhadap variabel terikat (Y), maka peneliti menggunakan rumus sebagai berikut (Riduwan,2007:125):

$$
t=\frac{r \sqrt{n-2}}{\sqrt{1-r^{2}}}
$$

Ho Diterima: Jika t-hit $\geq$ t-tab, artinya variabel $\mathrm{X}$ (Penempatan Karyawan dan Kompensasi) secara parsial berpengaruh tidak nyata terhadap Y (Kinerja Karyawan)

Ho Ditolak: Jika t-hit $<$ t-tab,

artinya variabel $\mathrm{X}$ (Penempatan Karyawan dan Kompensasi) secara parsial berpengaruh nyata terhadap $\mathrm{Y}$ (Kinerja Karyawan).

Kriteria pengambilan keputusannya adalah sebagai berikut:

Ho diterima jika t-hitung $>$ t-tabel, pada $\alpha=5 \%$

Ho ditolak jika t-hitung $<$ t-tabel, pada $\alpha=5 \%$

\section{Uji F}

Uji F dilakukan untuk membuktikan hipotesis awal tentang pangaruh Penempatan Karyawan $\left(\mathrm{X}_{1}\right)$ dan Kompensasi $\left(\mathrm{X}_{2}\right)$ secara bersamasama (simultan) sebagai variabel bebas terhadap Kinerja Karyawan (Y) sebagai variabel terikat dengan rumus sebagai berikut:

$$
F h=\frac{R^{2} / k}{\left(1-r^{2}\right) /(n-k-1)}
$$

Untuk mengetahui besarnya keseragaman $\mathrm{Y}$ yang dapat 
diterangkan oleh variabel $\mathrm{X}$ digunakan koefisien determinasi atau $\mathrm{R}^{2}$.

\section{Uji Koefisien Determinan $\left(\mathbf{R}^{2}\right)$}

Uji ini digunakan untuk melihat kontribusi variabel bebas, yaitu Penempatan karyawan $\left(\mathrm{X}_{1}\right)$, Kompensasi $\left(\mathrm{X}_{2}\right)$ terhadap Kinerja Karyawan (Y) sebagai variabel terikat. Untuk mengukur uji koefisien determinan dapat digunakan rumus sebagai berikut:

$$
R^{2}=\frac{b\left(n \sum X 1,2 Y\right)-\left(\sum X 1_{r}\right)(\Sigma Y)}{n\left(\Sigma Y^{2}\right)-(\Sigma Y)^{2}}
$$

Pengujian-pengujian diatas dilakukan dengan bantuan program pengelolahan data Statistical Packages for Sosial Science (SPSS).

\section{HASIL DAN PEMBAHASAN PENELITIAN}

\section{Hasil Penelitian}

\section{Uji Regresi Linier Berganda}

Pengujian melalui regresi

linier berganda dilakukan untuk menganalisis pengaruh penempatan karyawan dan kompensasi terhadap kinerja karyawan PT. Socfin Indonesia Medan. Sebagaimana hipotesis dalam penelitian ini :

H1 : Ada pengaruh Penempatan Karyawan $\left(\mathrm{X}_{1}\right)$ terhadap Kinerja Karyawan $(\mathrm{Y})$

$\mathrm{H} 2$ : Ada pengaruh Kompensasi $\left(\mathrm{X}_{2}\right)$ terhadap Kinerja Karyawan (Y)

H3 : Ada pengaruh Penempatan Karyawan $\left(\mathrm{X}_{1}\right)$ dan Kompensasi $\left(\mathrm{X}_{2}\right)$ terhadap Kinerja Karyawan (Y)

Adapun model regresi linier berganda adalah sebagai berikut:
Tabel 1. Koefisien Regresi Coefficients $^{\mathrm{a}}$

\begin{tabular}{|c|c|c|c|c|c|}
\hline \multirow[b]{2}{*}{ Model } & \multicolumn{2}{|c|}{$\begin{array}{l}\text { Unstandar } \\
\text { dized } \\
\text { Coefficient } \\
\text { s }\end{array}$} & \multirow{2}{*}{$\begin{array}{l}\begin{array}{l}\text { Standar } \\
\text { dized } \\
\text { Coeffici } \\
\text { ents }\end{array} \\
\text { Beta }\end{array}$} & \multirow[b]{2}{*}{$\mathrm{t}$} & \multirow[b]{2}{*}{$\begin{array}{l}\mathrm{Si} \\
\text { g. }\end{array}$} \\
\hline & B & \begin{tabular}{|l|} 
Std. \\
Erro \\
$\mathrm{r}$
\end{tabular} & & & \\
\hline $\begin{array}{l}1 \text { (Consta } \\
\text { nt) }\end{array}$ & $\begin{array}{l}17,5 \\
82\end{array}$ & $\begin{array}{l}3,34 \\
1\end{array}$ & & $\begin{array}{l}5,2 \\
62\end{array}$ & $\begin{array}{l}0 \\
00\end{array}$ \\
\hline $\begin{array}{l}\text { Penemp } \\
\text { atan }\end{array}$ & ,730 & ,139 & ,592 & $\begin{array}{l}5,2 \\
40\end{array}$ & $\begin{array}{l}, 0 \\
00\end{array}$ \\
\hline $\begin{array}{l}\text { Kompe } \\
\text { nsasi }\end{array}$ & 630, & ,114 & ,482 & $\begin{array}{l}4,6 \\
13 \\
\end{array}$ & $\begin{array}{l}, 0 \\
01\end{array}$ \\
\hline
\end{tabular}

Sumber : data diolah, 2016

Dari pengolahan data, maka dapat dibuat persamaan regresinya, yaitu:

$Y=17,582+0,730 x_{1}+0,630 x_{2}+e$

Persamaan regresi dapat dijelaskan sebagai berikut:

a. Konstan sebesar 17,582 menyatakan bahwa jika tidak ada kenaikan variabel penempatan karyawan $\left(\mathrm{X}_{1}\right)$ dan variabel kompensasi $\left(\mathrm{X}_{2}\right)$ maka nilai kinerja adalah sebesar 17,582.

b. Koefisien regresi variabel penempatan karyawan $\left(\mathrm{X}_{1}\right)$ sebesar 0,730 artinya jika setiap penambahan $1 \%$ nilai pada variabel penempatan karyawan $\left(\mathrm{X}_{1}\right)$ akan memberikan kenaikan nilai pada kinerja sebesar 0,730 .

c. Koefisien regresi variabel kompensasi $\left(\mathrm{X}_{2}\right)$ sebesar 0,630, artinya jika setiap penambahan $1 \%$ nilai pada variabel kompensasi $\left(\mathrm{X}_{2}\right)$ akan memberikan kenaikan pada kinerja sebesar 0,630. 


\section{Pengujian Hipotesis}

Pengujian Hipotesis Secara Parsial Menggunakan Uji-t

Untuk melihat besarnya pengaruh antara Penempatan Karyawan $\left(\mathrm{X}_{1}\right)$ dan Kompensasi $\left(\mathrm{X}_{1}\right)$ terhadap Kinerja Karyawan (Y) secara parsial, digunakan Uji t dengan menggunakan koefisien regresi.

a. Pengujian pengaruh penempatan karyawan $\left(\mathrm{X}_{1}\right)$ terhadap kinerja Karyawan (Y)

Secara individual uji statistik yang digunakan adalah uji t. Hasil perhitungan dengan program SPSS diperoleh t-hitung sebesar 5,240 dengan sig 0,000. Untuk memperoleh t-tabel dilakukan perhitungan sebagai berikut:

Taraf signifikansi $95 \%$ dan alpha $5 \%$ serta derajat kebebasan dengan ketentuan $\mathrm{dk}=\mathrm{n}-\mathrm{k}$ atau $63-3=$ 60. Dari ketentuan tersebut dipeoleh t-tabel sebesar 2,000. Nilai t-hitung yang diperoleh dari tabel koefisien sebesar 5,240>2,000, dengan sig $0,000<0,05$. Artinya terdapat pengaruh positif dan signifikan antara penempatan karyawan secara parsial terhadap kinerja karyawan PT. Socfin Indonesia Medan.

b. Pengujian pengaruh kompensasi $\left(\mathrm{X}_{2}\right)$ terhadap kinerja Karyawan (Y)

Secara individual uji statistik yang digunakan adalah uji t. Hasil perhitungan dengan program SPSS diperoleh t-hitung sebesar 4,613 dengan Sig 0,001. Untuk memperoleh t-tabel dilakukan perhitungan sebagai berikut:

Taraf signifikansi $95 \%$ dan alpha $5 \%$ serta derajat kebebasan dengan ketentuan $\mathrm{dk}=\mathrm{n}-\mathrm{k}$ atau $63-3=$ 60. Dari ketentuan tersebut dipeoleh t-tabel sebesar 2,000. Nilai t-hitung yang diperoleh dari tabel koefisien sebesar 4,163 > 2,000, dengan Sig $0,001<0,05$. Artinya terdapat pengaruh positif dan signifikan antara kompensasi secara parsial terhadap kinerja karyawan PT. Socfin Indonesia Medan.

Pengujian Hipotesis Secara Simultan Menggunakan Uji-F

Uji hipotesis secara simultan untuk mengetahui apakah model regresi sudah benar atau tidak. Uji hipotesis ini menggunakan taraf signifikan diperoleh dari tabel ANOVA berikut ini:

Tabel 2. Hasil Perhitungan Uji F ANOVA $^{\mathrm{a}}$

\begin{tabular}{|c|l|l|l|l|l|}
\hline & $\begin{array}{l}\text { Sum } \\
\text { of } \\
\text { Squar } \\
\text { es }\end{array}$ & $\begin{array}{l}\text { Mea } \\
\text { d } \\
\text { f }\end{array}$ & $\begin{array}{l}\text { Squa } \\
\text { re }\end{array}$ & F & Sig \\
\hline 1 Regres & 444,6 & 2 & 222,3 & 13,7 &, 00 \\
sion & 73 & 36 & 31 & $0^{\mathrm{b}}$ \\
Residu & 971,5 & 6 & 16,19 & & \\
al & 71 & 0 & 3 & & \\
Total & 1416, & 6 & & & \\
\hline
\end{tabular}

a. Dependent Variable: Kinerja

b. Predictors: (Constant), Kompensasi, Penempatan

Sumber: data diolah, 2016

Pada tabel 2.nilai $F$ hitung adalah sebesar 13,731, sedangkan nilai $\mathrm{F}$ tabelnya sebesar 3,15 (df $1=$ $3-1=2$ dan df $2=63-3=60$ ). Dengan nilai Signifikansi 0,000 lebih kecil dari taaraf signifikansi yaitu 0,05 . Karena $\mathrm{F}$ hitung $>$ F tabel $(13,731>$ $3,15)$ dan nilai signifikansi lebih kecil dari taraf signifikansi yaitu $0,000<$ 0,05 maka hipotesis ketiga diterima, yaitu terdapat pengaruh signifikan antara variabel penempatan karyawan dan kompensasi secara simultan terhadap kinerja karyawan PT. Socfin Indonesia Medan. 


\section{Koefisien Determinan (R Square) Tabel 3.R Square}

\begin{tabular}{|c|c|c|c|c|}
\hline \multicolumn{5}{|c|}{ Model Summary $^{b}$} \\
\hline Model & $\mathrm{R}$ & $\begin{array}{l}\mathrm{R} \\
\text { Square }\end{array}$ & $\begin{array}{l}\text { Adjusted } \\
\text { R Square }\end{array}$ & $\begin{array}{l}\text { Std. } \\
\text { Error of } \\
\text { the } \\
\text { Estimate }\end{array}$ \\
\hline 1 &, $560^{\mathrm{a}}$ &, 314 &, 291 & 4,02403 \\
\hline
\end{tabular}

Sumber : data diolah, 2016

Untuk mengetahui seberapa besar persentase pengaruh variabel bebas terhadap variabel terikat atau untuk melihat berapa besar variabel bebas dapat menjelaskan variabel terikat maka dilakukan pengujian koefisien determinasi $\left(\mathrm{R}^{2}\right)$

Dari tabel 4.13 dapat dilihat besarnya angka $R^{2}$ adalah 0,314 , yang artinya variabel $X_{1}$ dan $X_{2}$ menjelaskan pengaruh terhadap variabel $\mathrm{Y}$ sebesar 31,4\% $\left(\mathrm{R}^{2} \mathrm{X} 100 \%\right.$ ; $0,314 \times 100 \%=31,4 \%$ ) sedangkan sisanya $68,6 \%\left(100 \%-\mathrm{R}^{2}\right)$ dijelaskan oleh variabel-variabel diluar model penelitian ini.

\section{Pembahasan Hasil Penelitian}

Pengaruh Penempatan Karyawan Terhadap Kinerja Karyawan

Dari hasil uji regresi linier berganda diperoleh koefisien regresi variabel penempatan karyawan $\left(\mathrm{X}_{1}\right)$ sebesar 0,730 dengan signifikansi 0,000 . Yang berarti jika penempatan meningkat $1 \%$ maka kinerja karyawan mengalami peningkatan sebesar 0,730. Hasil perhitungan diperoleh nilai t hitung sebesar 5,240 dengan signifikansi 0,000 . Dengan demikian sig penelitian $<0,05$ maka hipotesis diterima. Yang berarti terdapat pengaruh yang signifikan antara penempatan karyawan secara parsial terhadap kinerja karyawan PT Socfin Indonesia. Hasil penelitian ini mendukung penelitian Asri Nur Fadilah, dkk (2015) menunjukkan bahwa variabel kesesuaian pengetahuan, kesesuaian kemampuan dan kesesuaian keahlian masingmasing berpengaruh signifikan terhadap kinerja pegawai,

\section{Pengaruh Kompensasi Terhadap}

\section{Kinerja Karyawan}

Dari hasil uji regresi linier berganda diperoleh koefisien regresi variabel kompensasi $\left(\mathrm{X}_{2}\right)$ sebesar 0,630 dengan signifikansi 0,001, yang artinya jika kompensasi meningkat $1 \%$, maka Kinerja Karyawan (Y) mengalami peningkatan sebesar 0,630 . Hasil perhitungan nilai thitung sebesar 4,163 dengan signifikansi 0,001. Dengan demikian Sig penelitian $<0$,maka hipotesis diterima. Yang berarti terdapat pengaruh yang signifikan antara kompensasi secara parsial terhadap kinerja karyawan PT Socfin Indonesia. Hasil penelitian ini mendukung penelitian yang dilakukan oleh Edrick Leonardo dan Fransisca Andreani (2015) Kompensasi non finansial mempunyai pengaruh positif dan signifikan terhadap kinerja karyawan. kompensasi finansial juga memiliki pengaruh positif dan signifikan terhadap kinerja karyawan.

Pengaruh Penempatan Karyawan dan Kompensasi Terhadap Kinerja Karyawan

Dari hasil perhitungan uji $\mathrm{F}$ dimana sig penelitian diperoleh 0,000 , dengan angka sig penelitian $<0,05$ maka hipotesis diterima. Yang berarti terdapat pengaruh yang signifikan antara variabel penempatan karyawan dan kompensasi secara simultan 
terhadap kinerja karyawan PT Socfin Indonesia. Dari perhitungan koefisien determinan diketahui besarnya angka $\mathrm{R}^{2}$ adalah $0,314(31,4 \%)$ yang berarti variabel kinerja karyawan dijelaskan sebesar $31,4 \%$ oleh variabel penempatan karyawan dan kompensasi sedangkan sisanya $68,6 \%$ dijelaskan oleh variabel lain diluar model penelitan ini. Hasil penelitian ini mendukung penelitian yang dilakukan oleh Asri Nur Fadilah, dkk (2015) yang menunjukkan terdapat pengaruh positif dan signifikan secara simultan maupun parsial antara penempatan dan kompensasi terhadap kinerja karyawan. Ini berarti bahwa penempatan maupun kompensasi memiliki peranan, baik secara simultan dan parsial dalam peningkatan kinerja karyawan.

\section{PENUTUP}

Berdasarkan hasil analisis yang diperoleh dan pembahasan dalam penelitian ini, terdapat beberapa kesimpulan yaitu sebagai berikut:

1. Dari hasil penelitian pada PT Socfin Indonesia Medan bahwa variabel penempatan karyawan berpengaruh positif dan signifikan terhadap kinerja karyawan PT Socfin Indonesia Medan, hal ini dilihat dari hasil perhitungan uji t yang dilakukan. Dimana $t$ hitung $>\mathrm{t}$ tabel dengan sig penelitian sebesar 0,000 .

2. Kompensasi berpengaruh poaitif dan signifikan terhadap kinerja karyawan PT Socfin Indonesia Medan, hal ini dilihat dari hasil perhitungan uji t yang dilakukan. Dimana $\mathrm{t}$ hitung $>\mathrm{t}$ tabel dengan sig penelitian sebesar 0,001 .

3. Variabel Penempatan Karyawan dan Kompensasi secara bersama- sama mempengaruhi Kinerja Karyawan PT Socfin Indonesia , hal ini dapat dilihat dari hasil perhitungan uji-F dimana Sig penelitian yang diperoleh dari hasil perhitungan sebesar 0,000 .

4. Diperoleh hasil $\mathrm{R}^{2}$ sebesar 0,314 , yang berarti Penempatan Karyawan dan Kompensasi menjelaskan pengaruh terhadap Kinerja Karyawan sebesar 31,4\% sedangkan sisanya $68,6 \%$ dijelaskan oleh variabel lain diluar model penelitian ini.

\section{DAFTAR PUSTAKA}

Ardana, I Komang dkk. 2012. Manajemen Sumber Daya Manusia.Yogyakarta : Graha Ilmu.

Arikunto, Suharsimi. 2010. Prosedur Penelitian Suatu Pendekatan Praktik. (Edisi Revisi 2010). Yogyakarta : PT. Rineka Cipta

Dessler, Garry. 2005. Manajemen sumber daya manusia. Edisi kesembilan, Jilid dua. Jakarta : Indeks.

Fadillah, Asri Nur. Abdul Hakim. Siswidiyanto. 2012. Pengaruh Penempatan Pegawai terhadap Kinerja (Studi pada Pegawai Sekretariat Daerah Kabupaten Gresik). Jurnal Administrasi Publik (JAP), Vol. 1, No. 5, Hal. 847-852

Hasibuan, Malayu S.P. 2005. Manajemen Sumber Daya Manusia. Jakarta : Bumi Aksara.

Hasibuan, Malayu S.P. 2008. Manajemen Sumber Daya Manusia, Edisi Revisi. Jakarta : Bumi Aksara. 
Lamalewa, Funnisia. Maupa, Harris. Taba, Muh.Idris. 2014. Pengaruh Kompensasi dan Kepuasan Kerja terhadap Kinerja Karyawan melalui Motivasi Kerja pada Bank di Kota Merauke. Jurnal Manajemen Fakultas Ekonomi Universitas Musamus Merauke.

Leonardo, Edrick. Fransisca Andreani. 2015. Pengaruh Pemberian Kompensasi terhadap Kinerja Karyawan PT. Kopanitia. Jurnal AGORA, Vol. 3. No. 2, Hal. 28-31.

Mangkunegara, A. A. Anwar Prabu. 2004. Manajemen Sumber Daya Manusia Perusahaan. Cetakan Kelima, Bandung : PT. Remaja Rosdakarya.

Mardiana, Nova. 2014. Pengaruh Penempatan dan Kompensasi terhadap Kinerja Karyawan PT.ASDP (Persero) Cabang Bakauheni. Jurnal SEMBISTEK 2014 IBI DARMAJAYA, hlm.160176

Mathis, L.R dan J.H Jackson. 2006. Manajemen Sumber Daya Manusia ( Human Resource Development). Jakarta : Salemba Empat.

Mulyadi. 2004. Akuntansi Manajemen : Konsep, Manfaat dan Rekayasa. Edisi Ketiga Cetakan Ketiga, Jakarta : Salemba Empat.

Panggabean. 2004. Manejemen Sumber Daya Manusia. Bogor: Ghalia Indonesia.
Riani, Asri Laksmi. 2013. Manajemen Sumber Daya Manusia Masa Kini. Yogyakarta : Graha Ilmu.

Riduwan dan Akdon. 2007. Rumus dan Data Dalam Analisis Statistik Untuk Penelitian. Bandung: Alfabeta

Rivai. 2011. Manajemen Sumber Daya Manusia Untuk Perusahaan Dari Teori Ke Praktek. Jakarta : PT. Rajagrafindo Persada

Sastrohadiwiryo, Siswanto B., 2005. Manajemen Tenaga Kerja Indonesia, Bumi Aksara: Jakarta.

Simamora, Henry. 2006. Manajemen Sumber Daya Manusia, Edisi III. Yogyakarta: STIE YKPN.

Sugiyono. 2012. Metode Penelitian Kuantitatif Kualitatif dan $R \& D$. Bandung: Alfabeta

Susanta, I Wayan Niko. Mayun Nadiasa. Ida Bagus Rai Adnyana, 2013. Pengaruh Kompensasi dan Kepemimpinan terhadap Kinerja Karyawan pada Jasa Konstruksi di Denpasar. Jurnal Ilmiah Elektronik Infrastruktur Teknik Sipil, Volume 2 No 2. April 2013

Sutrisno, H. Edy. 2010. Budaya Organisasi. Jakarta : Kharisma Putra Utama.

Suwatno. 2003. Azas-azas Manajemen Sumber Daya Manusia. Bandung : Suci Press.

Suwatno. 2008. Manajemen Sumber Daya Manusia.Bandung Alfabeta. 
JURNAL PLANS

Penelitian Ilmu Manajemen \& Bisnis

ISSN: 1978-7057

E-ISSN: 2527-306X

Tika, Pabundi, 2006. Budaya Organisasi dan Peningkatan Kinerja Perusahaan, PT. Bumi Aksara, Jakarta.

Umar, Husein. 2008. Riset Sumber Daya Alam Manusia Dalam
Organisasi. Jakarta Gramedia Pustaka Umum

Wibowo. 2007. Manajemen Kinerja, Edisi Kedua. Jakarta : PT. Raja Grafindo Persada. 